\title{
Direct seeding of black spruce in northwestern Ontario: Temporal changes in seedbed coverage and receptivity
}

\author{
by R.L. Fleming and D.S. Mossa
}

Temporal changes in black spruce (Picea mariana [Mill.] B.S.P.) seedbed coverage and seedbed receptivity were investigated on coarse-textured upland sites near Thunder Bay $\left(48^{\circ} 25^{\prime} \mathrm{N} 89^{\circ} 15^{\prime} \mathrm{W}\right)$, in northwestern Ontario. Sowing was completed in May for three consecutive years following summer scarification at each of 12 sites. Infilling by organic debris reduced the proportion of receptive soil strata three to five years after scarification by $50-95 \%$. Receptive seedbed coverage declined more quickly on fresh Soil Moisture Regimes with a variety of deciduous trees and shrubs than on moist Soil Moisture Regimes dominated by eracaceous shrubs. Pioneer mosses, which are also good seedbeds, invaded moist sites more readily than fresh sites, and mitigated losses in seedbed coverage. Compact Sphagnum seedbeds in lowland depressions maintained good areal coverage much longer than did receptive upland soil strata. Seedling establishment ratios varied greatly among seeding years, seedbeds and sites, but there was an underlying trend of decreasing seedbed receptivity with time since scarification. Seedlings originating from the first seeding year were taller at age 7-10 than those originating from the second or third seeding years.

Key words: direct seeding, seedbed coverage, seedbed receptivity, scarification, black spruce, Picea mariana

\section{Introduction}

Current emphasis on low-cost harvesting/regeneration systems has renewed interest in both seed-based natural regeneration and direct seeding (Benson 1988; Jeglum 1990). Black spruce (Picea mariana (Mill.) B.S.P.) is particularly well suited for lowcost, seed-based regeneration systems because: (1) it forms extensive stands on sites characterized by limited productivity and relatively little competition (Viereck and Johnston 1990), (2) abundant seed is stored in and continually released from its semiserotinous cones each year (Haavisto 1978, 1982), and (3) seed of high viability can be cleaned and stored for considerable periods (Wang 1974; Janas and Haddon 1984).

Two principle requirements for successful seed-based regeneration are sufficient quantities of receptive seedbed and favorable microsite conditions associated with these seedbeds (Fraser 1981; Jeglum and Leblanc 1988). The areal coverage of different seedbeds changes with time as a result of slumping, erosion, litter fall and vegetation ingress (e.g. bryophyte development). In addition, seedbed receptivity, the suitability of a given seedbed for seedling establishment, often changes with time through settling, compaction and surface crust development, as well as with changes in microclimate and the development of competition (Arlidge 1967). While some authors suggest seedbed receptivity is highest soon after scar-

Canadian Forest Service, Natural Resources Canada, Ontario Region
Les changements dans le temps des lits d'ensemencement dans le cas de l'épinette noire (Picea mariana [Mill.] B.S.P.) ainsi que leur réceptivité ont été étudiés sur des sits à texture grossières des plateaux de la région de Thunder Bay $\left(48^{\circ} 25^{\prime} \mathrm{N} 89^{\circ} 15^{\prime} \mathrm{W}\right)$, dans le nord-ouest de l'Ontario. L'ensemencement a été complété en mai pour chacune des trois années consécutives de scarifiage estival réalisé sur chacun des 12 sites. Le remplissage occasionné par les débris organique a réduit de 50 à $95 \%$ la proportion de la strate de sol réceptive trois à cinq ans après le scarifiage. La réceptivité des lits d'ensemencement a diminué plus rapidement sur les sites où la teneur en humidité de sol était de niveau frais, sites couverts de divers arbres et arbustes feuillus, que sur les sites où la teneur en humidité du sol était de niveau humide, sites dominés par des arbustes de la famille des Éricacées. Les mousses pionnières qui constituent également un bon lit d'ensemencement, avaient envahi plus rapidement les sites humides que les sites frais, et contrecarré ainsi les pertes au niveau des lits d'ensemencement. Les lits d'ensemencement compacts formés de Sphagnum dans les dépressions des basses terres ont pu maintenir beaucoup plus longtemps de bonnes surfaces que les strates réceptives des plateaux. Les rations d'établissement des semis variaient beaucoup en fonction des années d'ensemencement, des lits d'ensemencement et des sites, mais on peut identifier une tendance indiquant une diminution de la réceptivité des lits d'ensemencement en fonction du temps écoulé depuis le scarifiage. Les semis issus de la première année d'ensemencement étaient plus grands 7 à 10 ans après leur germination que ceux issus de la deuxième ou troisième année d'ensemencement.

Mots clés: ensemencement direct, lits d'ensemencement, réceptivité des lits d'ensemencement, scarifiage, épinette noire, Picea mariana

ification (Brown 1973; Jeglum 1984), others contend that seedbed conditions remain conducive to seedling establishment for several years (Hellum 1973).

The objectives of this paper are: (1) to describe temporal changes in areal seedbed coverage following scarification on upland black spruce sites, (2) to investigate temporal changes in seedbed receptivity and subsequent seedling growth on these sites and (3) to discuss these changes in terms of seed-based regeneration prescriptions.

\section{Methods}

\section{Study Sites and Experimental Design}

Most study sites and experimental procedures were described previously [Fleming and Mossa $(1994,1995)]$. Briefly, the 12 sites were located $60-135 \mathrm{~km}$ north of Thunder Bay $\left(48^{\circ} 25^{\prime} \mathrm{N}\right.$ $89^{\circ} 15^{\prime} \mathrm{W}$ ), in the Boreal Forest Region (Rowe 1972), on soils derived from cobbly sandy till ground moraines and glaciofluvial deposits (Table 1). All sites were previously occupied by well-stocked Site Class 1-2 (Plonski 1974), 90- to 120-yearold black spruce or black spruce-jack pine stands which were clearcut less than three years before plot establishment. Data were collected also for peatland seedbeds from two unscarified, clearcut lowland depressions adjacent to the Lever Lake and Stonehouse Lake sites, using a similar experimental design.

Each experiment was set up using a randomized complete block design with three to five blocks. Within a given block, separate plots were assigned randomly to each of three consecutive 


\begin{tabular}{|c|c|c|c|c|c|c|}
\hline \multirow[b]{2}{*}{ Site } & \multirow[b]{2}{*}{$\begin{array}{c}\text { Seeding } \\
\text { years }\end{array}$} & \multicolumn{3}{|c|}{ B,C Horizon Soil } & \multicolumn{2}{|c|}{ NWO FEC } \\
\hline & & $\begin{array}{c}\text { Soil } \\
\text { depth }\end{array}$ & $\begin{array}{c}\text { Soil } \\
\text { texture }^{1}\end{array}$ & $\begin{array}{c}\text { Moisture } \\
\text { regime }^{1}\end{array}$ & $\begin{array}{c}\text { Soil } \\
\text { type }^{2}\end{array}$ & $\begin{array}{c}\text { Vegetation } \\
\text { type }^{2}\end{array}$ \\
\hline Lever Lake & $1979-81$ & $5-20$ & B:SivfS & 1 & SS3 & V33 \\
\hline McGaughey Lake & $1980-81$ & $70-100$ & $\begin{array}{l}\text { B:SivfS } \\
\text { C:SiL }\end{array}$ & 6 & SS8-9 & V19 \\
\hline Goodlad Lake A & $1981-83$ & $>100$ & $\begin{array}{l}\text { B:SiL } \\
\text { C:LfS }\end{array}$ & 2 & S2 & V19 \\
\hline Goodlad Lake B & $1981-83$ & $>100$ & $\begin{array}{l}\text { B:SiL } \\
\text { C:SivfS }\end{array}$ & 4 & S8 & V19 \\
\hline Grew River A & $1981-83$ & $>100$ & $\begin{array}{l}\text { B:SivfS } \\
\text { C:SivfS }\end{array}$ & 2 & S3 & V33 \\
\hline Grew River B & $1981-83$ & $>100$ & $\begin{array}{l}\text { B:SivfS } \\
\text { C:SivfS }\end{array}$ & 5 & S8 & V34 \\
\hline Colwill Lake & $1982-84$ & $>100$ & $\begin{array}{l}\text { B:SiL } \\
\text { C:vfS }\end{array}$ & 2 & S2 & V18 \\
\hline Stonehouse Lake A & $1982-84$ & $>100$ & $\begin{array}{l}\text { B:SivfS } \\
\text { C:SivfS }\end{array}$ & 5 & $\mathrm{~S} 8, \mathrm{~S} 11$ & V34 \\
\hline Stonehouse Lake B & $1982-84$ & $>100$ & $\begin{array}{l}\text { B:SiL } \\
\text { C:vfS }\end{array}$ & 3 & S2 & V33 \\
\hline Kearns Lake A & $1984-86$ & $>100$ & $\begin{array}{l}\text { B:SivfS } \\
\text { C:SifS }\end{array}$ & 1 & S3 & V32 \\
\hline Kearns Lake B & $1984-86$ & $>100$ & $\begin{array}{l}\text { B:SivfS } \\
\text { C:SiL }\end{array}$ & 4 & S8 & V33 \\
\hline Manchester Lake & $1985-87$ & $40-100$ & $\begin{array}{l}\text { B:SivfS } \\
\text { C:SifS }\end{array}$ & 5 & SS6,SS8 & V34 \\
\hline
\end{tabular}

${ }^{1}$ Ontario Institute of Pedology (1985).

${ }^{2}$ Northwestern Ontario Forest Ecosystem Classification types (Sims et al. 1989).

years of May seeding, commencing the spring following summer or fall scarification. Scarification was performed with a TTS model 35 Disc Trencher, a CFS Row Scarifier or a modified Cazes and Heppner $(\mathrm{C} \& \mathrm{H})$ reforestation plow (Fleming et al. 1987). The actual scarifier used had little direct effect on the morphological seedbed types examined but did alter the microsite in a distinctive fashion.

At Goodlad Lake and Grew River, 45 rows of five equally spaced seedspots, representing five microsite positions across the $2.5 \mathrm{~m}$-wide scarified furrow (Fig. 1), were set up in each plot. Wherever possible, these seedspots were placed on Thin-F or shallow-mineral seedbeds, the two most common upland receptive soil strata following scarification (Jeglum 1984; Fleming and Mossa 1994). At the remaining eight upland sites and the two lowland sites, 30-50 seedspots were set up within each plot on each of six to nine commonly occurring seedbed types. At all sites each seedspot consisted of five surface-sown black spruce seeds. Germination percentages of seedlots ranged from 89 to $99 \%$.

The principal seedbed type of each seedspot was classified by surface morphology at the time of seeding. Seedbed types included commonly occurring soil strata (litter, thick-F, thin-F, thin-H, shallow-mineral and deep-mineral) and generic moss types (feather moss, pioneer moss, compact Sphagnum and loose Sphagnum) (Table 2) (Fleming and Mossa 1994). A soil pit was dug in each plot to assess soil characteristics including Soil Moisture Regime (Ontario Institute of Pedology 1985) and Northwestern Ontario Forest Ecosystem Classification soil type (Sims et al. 1989).

Assessments of seedbed coverage, and seedling survival and growth, were conducted in late summer of the first, second, third and fifth growing seasons for each seeding at each site. The predominant seedbed type and the number and height of surviving seedlings were recorded for each seedspot at each assess-

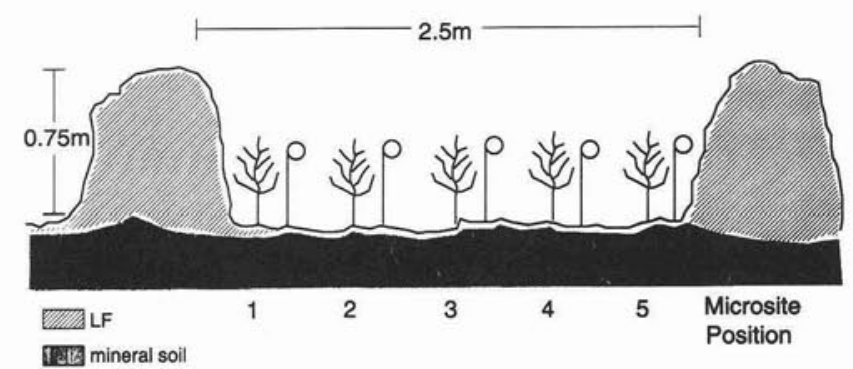

Fig. 1. Layout of seedspots at Goodlad Lake and Grew River across sacrified furrows created with a modified C\&H plow, showing the five microsite positions.

ment. To avoid confounding, only data from seedspots established in the first seeding year of each experiment (i.e. seeded within 10 months of scarification) were used to examine temporal changes in seedbed coverage. In August, 1992, additional assessments of seedling survival and height increment were conducted for all seeding years and site types at Kearns Lake, Goodlad Lake and Grew River.

An automated weather station, consisting either of a mechanical weather station with strip chart recorder (1979-1983) (Meteorology Research Inc., Atadena, CA) or a datalogger (Campbell Scientific Inc., Logan, UT, Model 21X) and associated sensors (1984-1989) was installed near the study sites. Mean hourly values of precipitation, as well as several other variables, were recorded continuously during the growing season. Weather data was also obtained for the 1979-1989 growing seasons from the Environment Canada, Atmospheric Environment Service weather station at Thunder Bay (Station $61)$. 
Table 2. Seedbed types, defined in terms of morphologic characteristics, thickness or depth (Ontario Institute of Pedology 1985; Sims et al. 1989)

\begin{tabular}{|c|c|c|}
\hline $\begin{array}{l}\text { Seedbed } \\
\text { type }\end{array}$ & Definition & $\begin{array}{l}\text { Distance from mineral soil- } \\
\text { humus interface }\end{array}$ \\
\hline litter & Undecomposed organic matter (L horizon) & $>5 \mathrm{~cm}$ above the interface \\
\hline thick-F & Partially decomposed organic matter (F horizon) & $>5 \mathrm{~cm}$ above the interface \\
\hline thin-F & Partially decomposed organic matter (F horizon) & $\leq 5 \mathrm{~cm}$ above the interface \\
\hline thin-H & Well-decomposed organic matter $\left(\mathrm{H}, \mathrm{H}_{\mathrm{i}}\right.$ horizon) & $\leq 5 \mathrm{~cm}$ above the interface \\
\hline shallow-mineral & $\mathrm{A}_{e}, \mathrm{~B}$ mineral soil horizons & $\leq 10 \mathrm{~cm}$ below the interface \\
\hline deep-mineral & $\mathrm{B}, \mathrm{C}$ mineral soil horizons & $>10 \mathrm{~cm}$ below the interface \\
\hline pioneer moss & \multicolumn{2}{|c|}{ Pohlia neutans, Ceratadon purpureus, Poltrichum juniperinum and Polytrichum commune $(\leq 5 \mathrm{~cm}$ tall) } \\
\hline feather moss & \multicolumn{2}{|c|}{ Pleurozium schreberi, Dicranum polysetum, Ptilium crista-castrensis, Hylocomium splendens } \\
\hline compact Sphagnum & \multicolumn{2}{|c|}{ Slow-growing varieties of Sphagnum moss that often form dense, compact mounds } \\
\hline Sphagnum peat, in situ & \multicolumn{2}{|c|}{ Beige to yellow-brown, poorly decomposed Sphagnum mosses } \\
\hline displaced Sphagnum peat & \multicolumn{2}{|c|}{$\begin{array}{l}\text { Poorly decomposed Sphagnum moss detached by harvesting or site preparation and deposited on the } \\
\text { ground surface }\end{array}$} \\
\hline
\end{tabular}

\section{Data Analysis}

Temporal changes in receptive seedbed coverage were fitted to a reciprocal function of the form:

$$
P=1 /\left(1+A t^{B}\right)
$$

where $P$ is the proportional coverage in relation to that soon after scarification (i.e. at the time of seedspot establishmentyear zero), $t$ is time (years) since scarification, and $A$ and $B$ are fitted parameters.

Fifth year seedling establishment ratios (surviving seedlings/seed sown after five growing seasons) were transformed ( $p^{\prime}=\arcsin$ $\left.p^{0.5}\right)$ (Zar 1984) and then analyzed using two-way ANOVA with seedbed and seeding year as fixed-effect variables. Significant differences $(p \leq 0.10)$ among individual seeding years were identified using Newman-Keuls multiple comparison test.

Seedling heights at a given age and site were compared using two-way ANOVA with seedbed and seeding year as fixedeffect variables. Seedling height distributions for most seedbed - seeding year - site combinations were positively skewed and were log-transformed to improve normality and homoscedasticity before statistical tests. Levene's test for equality of variances indicated very few significant departures $(p<0.10)$ from equality following data transformation. Significant differences $(p \leq 0.10)$ among individual seedbeds and seeding years were identified using Newman-Keuls multiple comparison test.

\section{Results and Discussion}

\section{Changes in Seedbed Coverage}

There was a marked increase in the areal coverage of deep organic seedbeds (thick-F and litter, both poor seedbeds) and a marked decrease in the areal coverage of thin-F, thin- $\mathrm{H}$ and shallow-mineral seedbeds, the principal receptive soil strata (Fleming and Mossa 1994), with time since scarification (Fig. 2). This shift in seedbed coverage began within a year of scarification, and after five years the coverage of thin-F, thin$\mathrm{H}$ and shallow-mineral seedbeds was reduced by $50-95 \%$ on the different sites.

The most rapid declines in seedbed coverage occurred with thin-H. This seedbed, with its amorphous, colloidal structure and thin, discontinuous nature was rapidly dissipated by washing, leaching and decomposition. In most instances, the coverage of this seedbed was reduced by $>50 \%$ within a year of scarification, and within five years of scarification $<10 \%$ of this seedbed remained on any of the sites. Most thin- $\mathrm{H}$ seedbeds
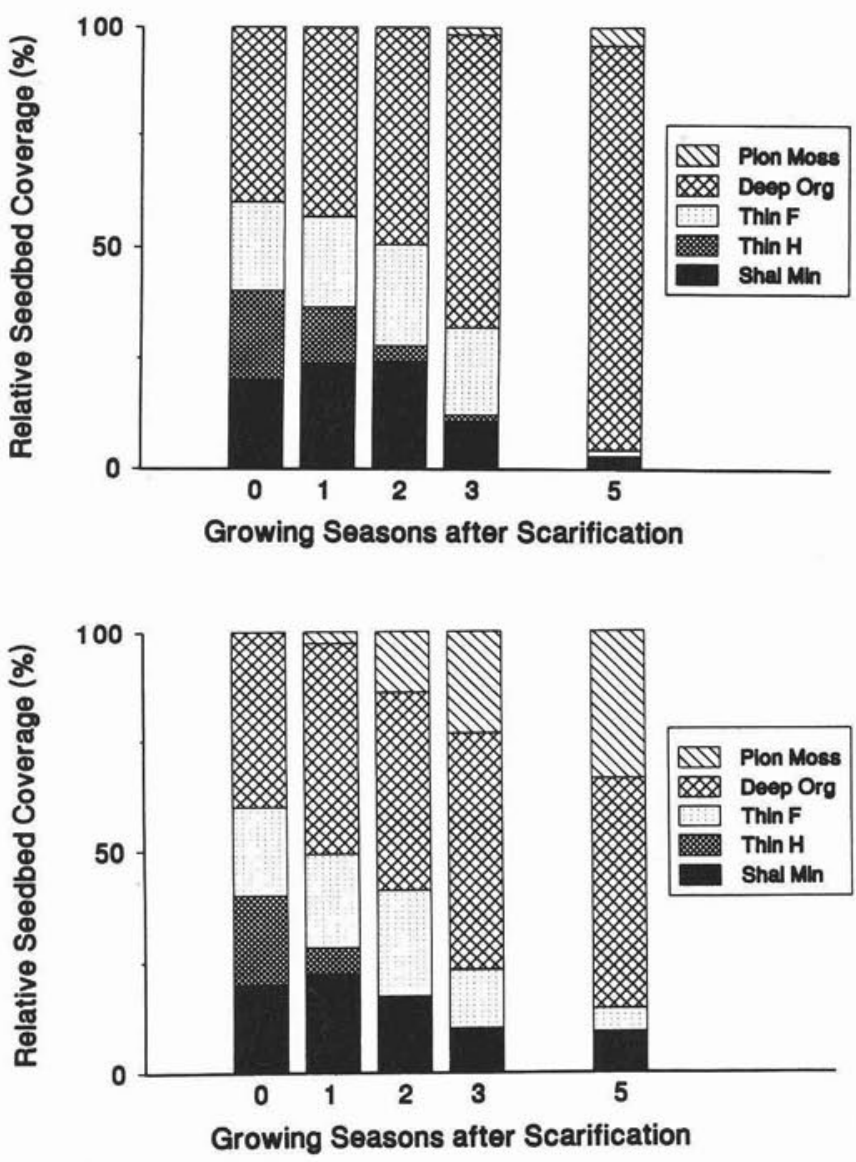

Fig. 2. Temporal changes in relative seedbed coverage following scarification at: (a) Colwill Lake (NWO FEC V18, S2) and (b) Manchester Lake (NWO FEC V34, SS6, 8). Results are based on 150 seedspots sown on shallow-mineral (Shal Min), thin-H, thin-F and litter. Data for thick-F and litter seedbeds were combined into one category, deep organic (Deep Org). Ingress of pioneer moss (Pion Moss) is also shown. Seedspots were established in May following scarification the previous summer, and changes in seedbed coverage were assessed in late August of the first, second, third and fifth growing seasons.

reverted to thin-F or shallow-mineral seedbeds initially, and subsequently, to litter or thick-F seedbeds.

Thin-F seedbeds maintained substantial coverage for a much longer period. Most changes in this seedbed type occurred three to five years after scarification, as it reverted 
primarily to litter and thick-F on the drier sites, dense graminoid mats on the most productive sites, and pioneer mosses on the moister sites.

Shallow-mineral seedbeds usually retained $>50 \%$ of their original areal coverage for at least two years following scarification. Between years three and five, however, there was often a substantial decline in coverage, reflecting both litter accumulation and, particularly on moist sites, pioneer moss invasion. For instance, five years after scarification at Kearns Lake, pioneer moss and deep organic seedbeds occupied $46 \%$ and $42 \%$, respectively, of the original shallow-mineral seedbeds on fresh Soil Moisture Regimes (NWO FEC S3 sites) (Fig. 3a), in comparison with $68 \%$ and $20 \%$, respectively, of the original shallow-mineral seedbeds on moist Soil Moisture Regimes (NWO FEC S8 sites) (Fig. 3b).

Pioneer mosses invaded most sites within two to three years of scarification. The preferred substrates for these mosses were the receptive soil strata, particularly shallow-mineral, and moss ingress was most pronounced on moist sites not subject to heavy grass competition. In their initial stages of development, pioneer mosses are good black spruce seedbeds (MacLean 1959; Jeglum 1984; Fleming and Mossa 1994), although later they often become too tall and dense for seedling establishment (Place 1955). From this perspective, shallow-mineral may provide the most long-lasting receptive seedbed media, particularly on moister sites, because this soil strata is readily invaded by pioneer mosses. Greater pioneer moss ingress on the moist sites likely reflects both abundant near-surface moisture and lack of heavy litter fall.

The proportion of receptive upland soil strata usually decreased slightly more rapidly on fresh (moderately fresh to fresh Soil Moisture Regimes) than on moist (moderately moist to moist Soil Moisture Regimes) sites (Fig. 4); (Table 3). The proportion of receptive upland seedbed (receptive upland soil strata + pioneer moss), however, decreased much more rapidly on the fresh than on the moist sites (Fig. 5). Five years after seeding, the mean coverage of receptive seedbed had fallen by about $70 \%$ on the fresh sites, compared with $25 \%$ on the moist sites.

Leaf litter accumulation was the principal cause for the decline in receptive seedbed coverage. The more rapid decrease in coverage on fresh than on moist sites reflected the composition of vegetation and hence the type and quantity of litter fall. Fresh sites usually supported a variety of herbs, broad-leafed shrubs and deciduous trees, including white birch (Betula papyrifera Marsh.), trembling aspen (Populus tremuloides Michx.), pin cherry (Prunus pensylvanica L.f.), alder (Alnus crispa (Ait.) Pursh and Alnus rugosa (Du Roi) Spreng.), dwarf raspberry (Rubus pubescens Raf.) and Amelanchier species. Moist sites, in contrast, were usually dominated by eracaceous shrubs such as blueberry (Vaccinium angustifolium Ait. and Vacinium myrtilloides Michx.) and Laborador tea (Ledum groenlandicum Oeder) which produced considerably less leaf litter.

Seedbed coverage and its rate of change also varied with microsite position (Fig. 6). Soon after scarification with the $\mathrm{C} \& \mathrm{H}$ plow there was greater coverage of thin-F near the sides of the furrows, and of shallow-mineral near the middle of the furrows. Litter began covering substantial quantities of these seedbeds by year three, and by year five covered $20-30 \%$ of the original receptive soil strata at the Grew River sites and 55-60\%
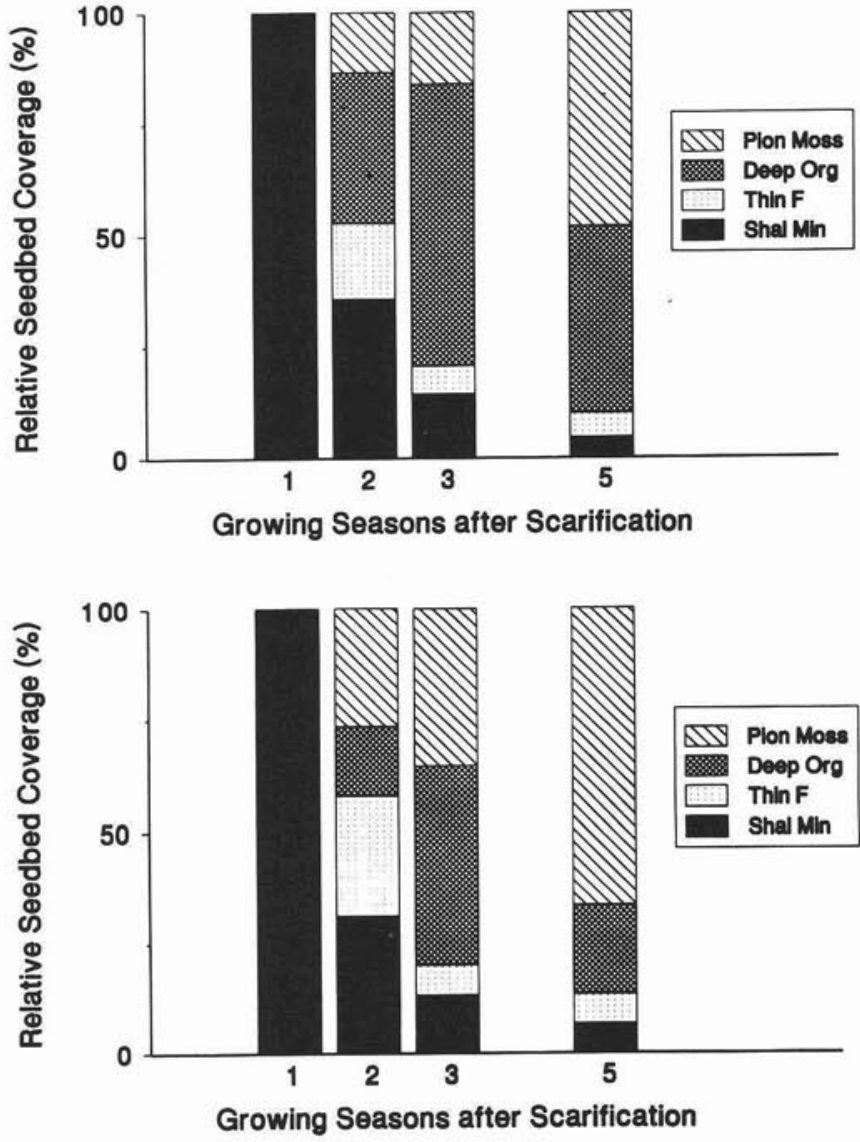

Fig. 3. Temporal changes in the composition of seedbeds initially classified as shallow-mineral following scarification at (a) Kearns Lake A (NWO FEC S3) and (b) Kearns Lake B (NWO FEC S8). Data for thick-F and litter seedbeds were combined into one category, deep organic (Deep Org).

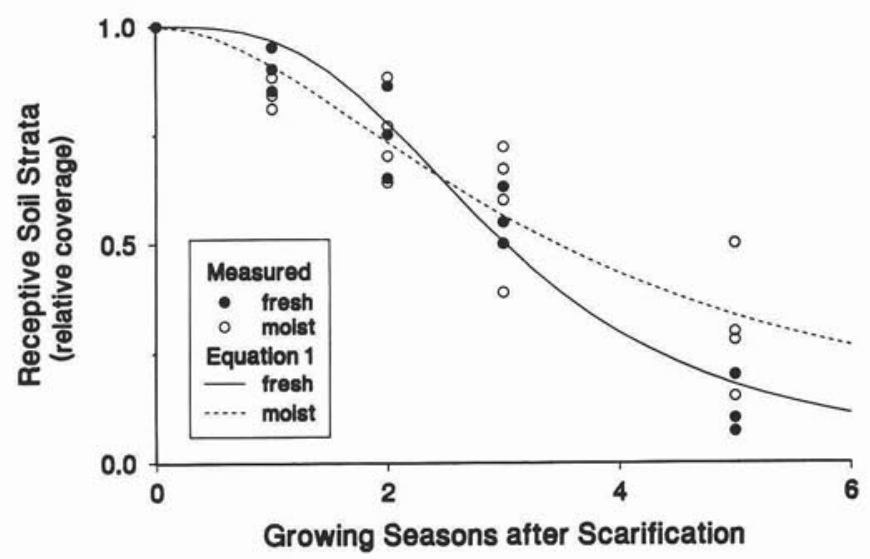

Fig. 4. Temporal change in the relative areal coverage of receptive upland soil strata (thin-F, thin-H and shallow-mineral seedbeds) following scarification on moderately fresh to fresh Soil Moisture Regimes and on moderately moist to moist Soil Moisture Regimes.

of the receptive soil strata at the Goodlad Lake sites. At both locations litter seedbeds occurred most frequently near the edges of the furrow.

Pioneer moss ingress at Grew River and Goodlad Lake was related to microsite position and site type. Five years 
Table 3. Parameter values and associated standard errors (SE), $F$ ratios and $R^{2}$ values for the best-fit equations (Eq. 1) relating proportional changes in receptive soil strata and seedbed (soil strata + pioneer moss) coverage to time since scarification, for different Soil Moisture Regimes (Figs. 4-5). All equations are of the form $P=1 /\left(1+A t^{B}\right)$ where $P$ is proportional coverage in relation to that soon after scarification (year zero), $t$ is time (growing seasons) since scarification and $A$ and $B$ are fitted parameters.

\begin{tabular}{|c|c|c|c|c|}
\hline \multirow{3}{*}{$\begin{array}{l}\text { Parameter } \\
\text { or } \\
\text { measure }\end{array}$} & \multicolumn{4}{|c|}{ Soil moisture regime } \\
\hline & \multicolumn{2}{|c|}{ Moderately fresh-fresh } & \multicolumn{2}{|c|}{ Moderately moist-moist } \\
\hline & $\begin{array}{l}\text { Receptive } \\
\text { soil strata }\end{array}$ & $\begin{array}{c}\text { Receptive } \\
\text { seedbed }\end{array}$ & $\begin{array}{l}\text { Receptive } \\
\text { soil strata }\end{array}$ & $\begin{array}{c}\text { Receptive } \\
\text { seedbed }\end{array}$ \\
\hline A & 0.0353 & 0.0792 & 0.1029 & 0.1542 \\
\hline SE (A) & 0.0165 & 0.0293 & 0.0367 & 0.0191 \\
\hline B & 3.0291 & 2.1305 & 1.8344 & 0.5160 \\
\hline SE (B) & 0.4145 & 0.3140 & 0.2999 & 0.1046 \\
\hline$F$-Ratio & 234.8 & 147.0 & 110.7 & 123.6 \\
\hline$R^{2}$ & 0.948 & 0.918 & 0.860 & 0.873 \\
\hline
\end{tabular}

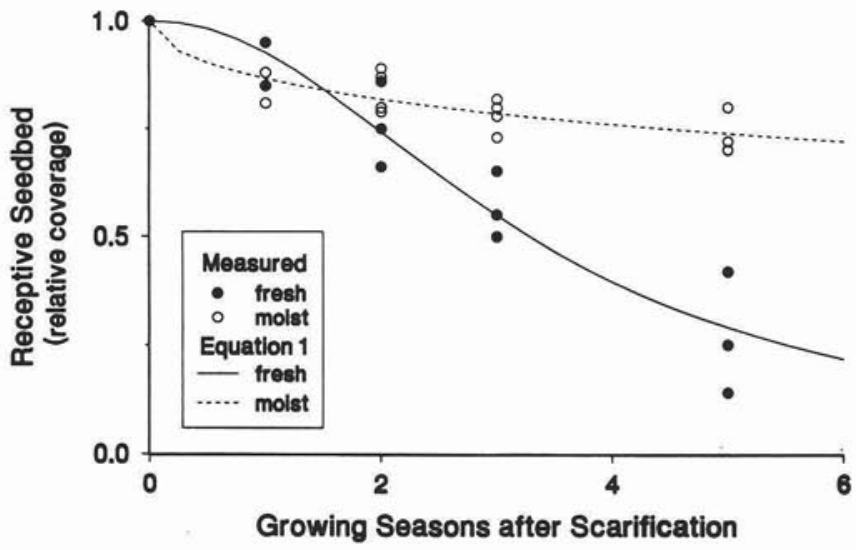

Fig. 5. Temporal change in the relative areal coverage of receptive upland seedbed (receptive upland soil strata + pioneer moss) following scarification on moderately fresh to fresh Soil Moisture Regimes and on moderately moist to moist Soil Moisture Regimes.

after scarification at Grew River and Goodlad Lake, pioneer mosses had invaded $3-8 \%$ of the receptive soil strata on the drier sites (NWO FEC S 2-3) and 14-33\% of the receptive soil strata on the moister sites (NWO FEC S8). At all sites, these mosses were more prevalent in the middle as opposed to near the edges of the furrows.

Eventually litter accumulation, pioneer moss growth and the development of surface crusts and lichen mats (e.g. Cladonia and Cladina species) greatly reduce receptive seedbed quantities on all upland types (MacLean 1959; Jeglum 1984). Five growing seasons after scarification, the mean coverage of receptive soil strata had been reduced by $80 \%$ on the fresh Soil Moisture Regimes and $65 \%$ on the moist Soil Moisture Regimes, and most pioneer mosses (i.e. Polytrichum species) were becoming too tall and dense to serve as good seedbeds (Place 1955; MacLean 1959).

In contrast to upland sites, there was little change in the areal coverage of compact Sphagnum, the most common receptive seedbed on many peatland sites (Groot and Adams 1994). Five years after seeding the two lowland depressions, over $70 \%$ of the original compact Sphagnum seedbed was still classed as such, and a further $10-15 \%$ was classed as poorly decomposed
Sphagnum peat, in situ (also a good seedbed). In addition, 10-25\% of the displaced poorly decomposed Sphagnum seedbeds had been invaded by compact Sphagnum by this time. The maintenance of large quantities of compact Sphagnum is attributed to the small accumulations of leaf litter on these Labrador teadominated sites, the growth of the Sphagnum itself, and microclimate conditions following clearcutting which are favorable to the development of compact Sphagnum growth forms (Berbee 1957; Clymo 1970; Jeglum 1979).

\section{Changes in Seedbed Receptivity and Growth Response}

Temporal changes in seedbed receptivity were evaluated using fifth-year seedling establishment ratios on thin-F and shallowmineral seedbeds.

\section{a. Establishment Ratios}

Although trends were not consistently strong, in many cases the best seedling establishment ratios were obtained with the first seeding (Table 4). Among the eleven study sites, the highest establishment ratios $(p \leq 0.10)$ on both thin-F and shallow-mineral seedbeds were attained four times in the first seeding year, once in the second seeding year and twice in the third seeding year. There was no significant difference $(P>0.10)$ in establishment ratios among seeding years for the remaining four study sites. The general decline in thin-F and shallow-mineral seedbed receptivity after the first growing season suggests that seedling establishment is better while these surfaces remain loose and friable.

Fifth year seedling establishment ratios often varied substantially among seeding years for a given seedbed type and study site (Fig. 7). The relative magnitude of these variations, however, was not strongly correlated with seedbed, Soil Moisture Regime or NWO FEC soil type. Mean establishment ratio coefficients of variation, calculated for the three seeding years at each of 11 different study sites, were 0.611 for thin-F seedbeds and 0.520 for shallow-mineral seedbeds.

This variability in establishment ratios for a given seedbed and site type highlights the importance of stochastic events such as drought, frost heaving, flooding, and insects and diseases in determining seeding success (LeBarron 1944; Winston 1975). These conditions often overshadowed the effects of seedbed maturation (i.e. seeding year) on seedling establishment. In the most favorable years, such as 1984, establishment ratios were usually high regardless of receptive seedbed type, site type or seeding year (Table 4). Likewise, unfavorable years such as 1982 resulted in poor establishment ratios on virtually all sites.

The high fifth-year establishment ratios found in virtually all 1984 seedings may reflect plentiful first growing season soil moisture. June rainfall was $40 \mathrm{~mm}$ above 30 year normals for that month, while July and August values were very close to their thirty year normals (Atmospheric Environment Service 1982). During 1984 there were a maximum of four days between rainfall events in both June and July, and a maximum of five days in August. In comparison, the mean maximum number of consecutive days without rain for the period 1979-1988, measured at these sites, were 5.6 days for June, 5.5 days for July and 6.7 days for August.

The poor results with the 1982 seedings reflected high mortality from frost heaving in the fall of 1982 and spring of 1983 (i.e. poor survivorship), rather than poor first growing season estab- 

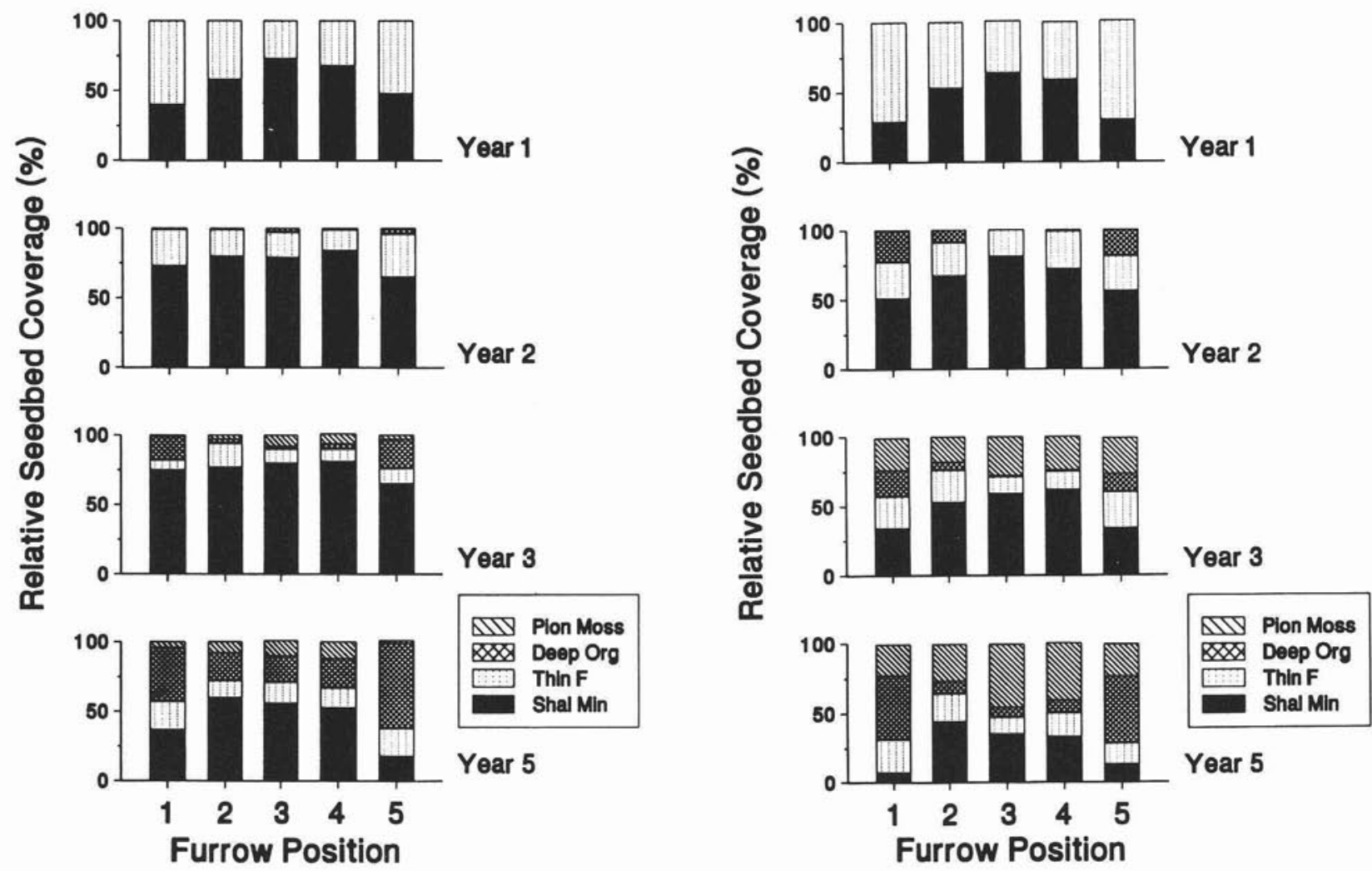

Fig. 6. Temporal changes in the composition of seedbeds initially classified as thin-F or shallow-mineral, by microsite position at (a) Grew River A (NWO FEC S3) and (b) Grew River B (NWO FEC S8). Symbols are the same as those used in Fig. 2.

\begin{tabular}{|c|c|c|c|c|c|c|c|c|c|c|c|}
\hline \multicolumn{3}{|c|}{ NWO FEC } & \multicolumn{9}{|c|}{ Year of seeding (19_) } \\
\hline Site & Soil type & Seedbed & 79 & 80 & 81 & 82 & 83 & 84 & 85 & 86 & 87 \\
\hline \multirow[t]{2}{*}{ Lever Lake } & SS4 & Thin-F & 2 & $1^{*}$ & 3 & & & & & & \\
\hline & & S. Min & 2 & $1 *$ & 3 & & & & & & \\
\hline \multirow[t]{2}{*}{ Stonehouse Lake B } & S2 & Thin-F & & & & 2 & 3 & $1 *$ & & & \\
\hline & & S. Min & & & & 3 & 2 & $1^{*}$ & & & \\
\hline \multirow{2}{*}{ Colwill Lake } & S2 & Thin-F & & & & 3 & 1 & 2 & & & \\
\hline & & S. Min & & & & 3 & 2 & 1 & & & \\
\hline \multirow[t]{2}{*}{ Goodlad Lake B } & S2 & Thin-F & & & $1 *$ & 2 & 3 & & & & \\
\hline & & S. Min & & & $1 *$ & 3 & 2 & & & & \\
\hline \multirow{2}{*}{ Grew River A } & S3 & Thin-F & & & 2 & 3 & 1 & & & & \\
\hline & & S. Min & & & 2 & 3 & 1 & & & & \\
\hline \multirow{2}{*}{ Kearns Lake A } & S3 & Thin-F & & & & & & $1 *$ & 2.5 & 2.5 & \\
\hline & & S. Min & & & & & & 1 & 3 & 2 & \\
\hline \multirow[t]{2}{*}{ Stonehouse Lake A } & S8 & Thin-F & & & & 3 & 2 & $1 *$ & & & \\
\hline & & S. Min & & & & 3 & 2 & $1 *$ & & & \\
\hline \multirow[t]{2}{*}{ Kearns Lake B } & S8 & Thin-F & & & & & & $1^{*}$ & 3 & 2 & \\
\hline & & S. Min & & & & & & $1 *$ & 3 & 2 & \\
\hline \multirow[t]{2}{*}{ Goodlad Lake A } & S8 & Thin-F & & & $1 *$ & 2 & 3 & & & & \\
\hline & & S. Min & & & $1^{*}$ & 2 & 3 & & & & \\
\hline \multirow[t]{2}{*}{ Grew River B } & S8 & Thin-F & & & 1 & 2 & 3 & & & & \\
\hline & & S. Min & & & 1 & 3 & 2 & & & & \\
\hline \multirow[t]{2}{*}{ Manchester Lake } & SS6, & Thin-F & & & & & & & $1 *$ & 2 & 3 \\
\hline & SS8 & S. Min & & & & & & & $1 *$ & 3 & 2 \\
\hline
\end{tabular}

*A superscript asterisk indicates a significant difference $(P \leq 0.10)$ between the year of highest ranking and other years for that location. Results from McGaughey Lake are not presented because there were only two seeding years at that site. 


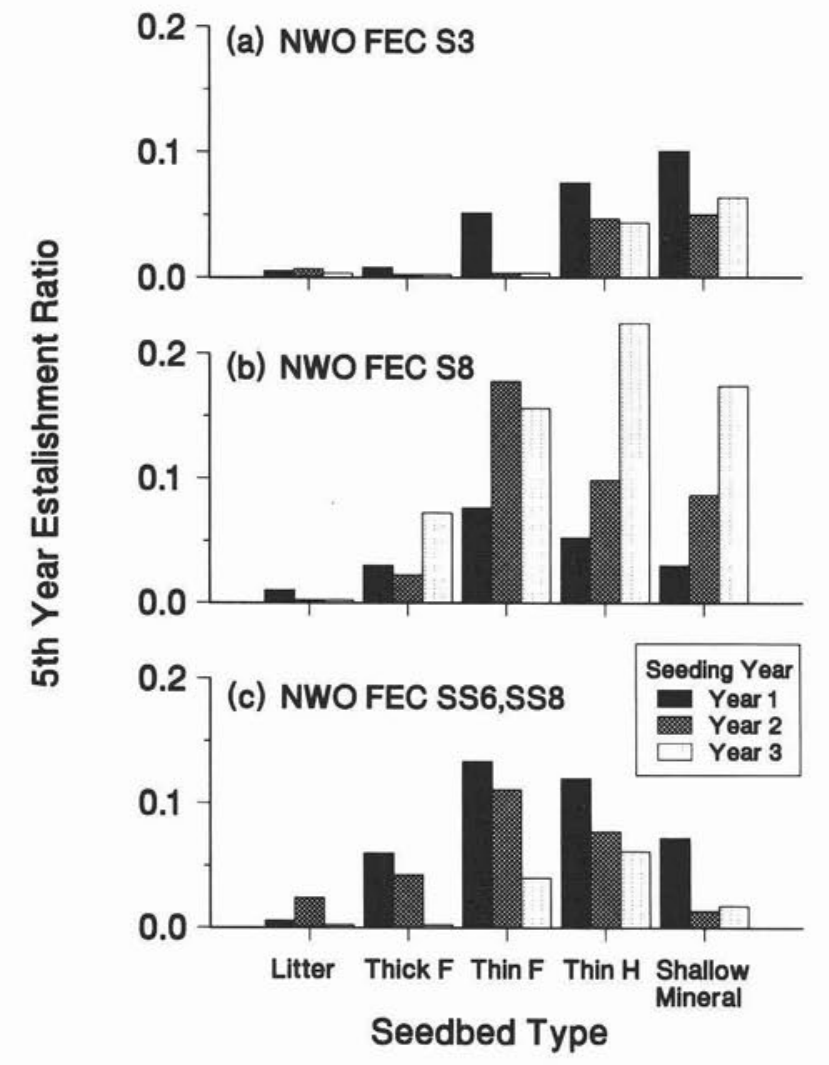

Fig. 7. Fifth year seedling establishment ratios (seedlings/viable seed sown) by year of seeding on selected upland seedbed types at: (a) Kearns Lake A (NWO FEC S3-fresh), (b) Stonehouse Lake A (NWO FEC S8-moist) and Manchester Lake (NWO FEC SS6, SS8moist).

lishment. Indeed, first growing season establishment ratios for the 1982 seedings were among the highest for any study year.

Fifth year survivorship $\left(S_{5}\right.$, where $S_{5}=z_{5} / z_{1}$, and $z_{5}$ and $z_{1}$ are the number of seedlings surviving at the end of the fifth and first growing seasons, respectively), also varied greatly, ranging from 0.05 to 0.85 among the different study site-seeding year combinations. There was little relationship, however, between seeding year and fifth year seedling survivorship, irrespective of seedbed type or Soil Moisture Regime.

\section{b. Seedling Growth}

In most cases there was no significant difference $(P>0.10)$ in fifth year seedling heights among different receptive seedbed types and seeding years at a given study site. However, subsequent measurements of seedling height at the Goodlad Lake, Grew River and Kearns Lake sites showed a different pattern. At Kearns Lake, total seedling heights seven years after sowing were greater for seedlings sown in the first seeding year than for seedlings sown in the second or third seeding year, regardless of site type (Fig. 8). Likewise, at Goodlad Lake and Grew River, total seedling heights ten years after sowing were greater for seedlings sown in the first seeding year than for seedlings sown in the second or third seeding year (Table 5). In addition, at Goodlad Lake seedlings from the second seeding year were taller $(P<0.10)$ at age 10 than those from the third seeding year. At these three locations there were no consistent

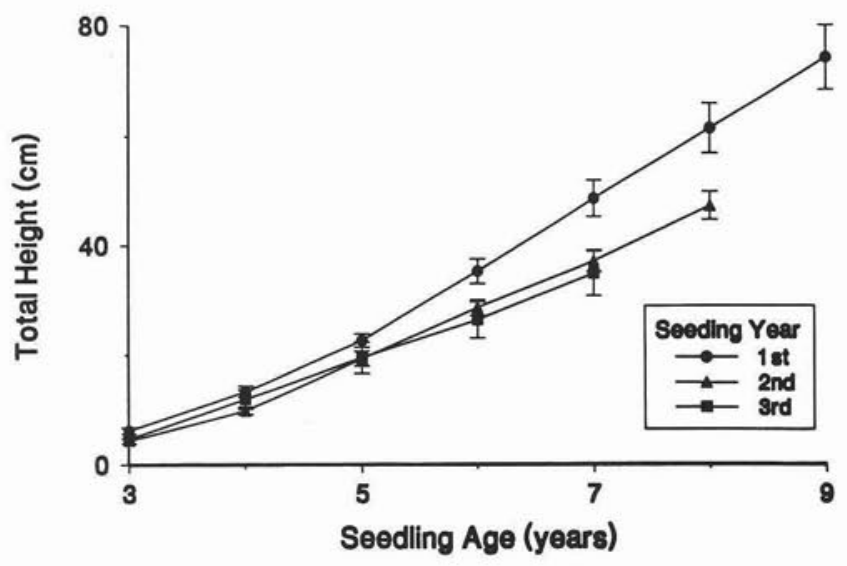

Fig. 8. Mean black spruce seedling heights at Kearns Lake (A and B) as a function of seedling age, for seedlings originating from the first, second and third year of seeding. Vertical bars represent the standard error for each mean value.

differences after 7-10 years in seedling height on different Soil Moisture Regimes (Fleming and Mossa 1995).

The slow manifestation of differences in seedling height at equivalent seedling ages among the three seeding years likely reflects both the lack of severe initial competition and the limited initial response of black spruce height increment to competition (Morris et al. 1990). The major difference in environmental conditions between the three consecutive years of seeding was the stage of development of competition. The principal competitors present $7-12$ years after seeding developed largely from seed which germinated after scarification, and it usually took these plants several years to attain competitive size and completely overtop the black spruce seedlings (Fleming and Mossa 1995).

\section{Silvicultural Implications}

The temporal decline in seedbed coverage and seedbed receptivity suggests that seed-based regeneration on these and similar sites will be most successful soon after scarification. To take advantage of this, aerial seeding should be conducted within a year of scarification, whereas scarification for seed-based natural regeneration should be completed during years with adequate cone crops (Jeglum 1987). Seeding (or reseeding) is unlikely to succeed if delayed for several years after scarification.

Comparisons of establishment ratios resulting from seeding immediately after scarification with those from seeding the spring following summer or fall scarification, as was done here, are needed. Brown (1973) and Rudolph (1973) contend that soil settling and slumping will reduce seedling establishment if seeds are sown immediately followed scarification, and the observations of MacLean (1959) support this conjecture. Soil compaction during scarification, however, may circumvent this problem (Van Damme 1988). Simultaneous scarification and ground seeding has great potential as a low-cost regeneration technique if seedbeds can be produced which are immediately conducive to seedling establishment. 
Table 5. Mean seedling heights at a given age for different seeding years at the Goodlad Lake and Grew River locations.

\begin{tabular}{lccc}
\hline Location & $\begin{array}{c}\text { Seeding } \\
\text { year }\end{array}$ & $\begin{array}{c}\text { Seedling age } \\
\text { at assessment } \\
\text { (yrs) }\end{array}$ & $\begin{array}{c}\text { Total } \\
\text { height } \\
(\mathbf{c m})\end{array}$ \\
\hline Goodlad Lake & 1981 & 10 & $83.2 a$ \\
& 1982 & 10 & $46.9 b$ \\
Grew River & 1983 & 10 & $33.8 \mathrm{c}$ \\
& 1981 & 10 & $67.8 a$ \\
& 1982 & 10 & $39.1 b$ \\
& 1983 & 10 & $34.6 b$ \\
\hline
\end{tabular}

$a$-cHeight data from both sites for a given location were not significantly different and were combined. There is no significant difference $(P>0.05)$ for a given location among seedling heights with the same lower case letter, as determined by ANOVA, followed by Newman-Keuls multiple comparison test.

The great variability in seedling establishment ratios among different years of seeding, regardless of seedbed age, is also noteworthy. Similar variations in seedling establishment were reported by MacLean (1959) and Jeglum (1984), and suggest that multiple seeding (i.e. seeding in consecutive years, beginning the first spring after scarification) may provide more consistent results than seeding only once.

The type of microsite created by scarification will also influence temporal declines in seedbed coverage. Microsite locations which trap litter, or are subject to slumping and infilling, experience the most rapid decreases in receptive seedbed coverage. Thus, greater temporal decreases in seedbed coverage can be expected near the sides than in the centre of scalped furrows, and with small, steep-sided depressions than with flatter, more expansive surfaces.

Control of woody vegetation is a requisite if these and similar sites are to be reforested to black spruce using seed-based regeneration techniques. Better growth of seedlings from the first seeding year than from subsequent seeding years is attributed largely to differences in the size and development of competitors. On sites subject to heavy herbaceous and/or graminoid competition, seeding soon after scarification is imperative if there is to be any chance of success (Arlidge 1967; Richardson 1972; Dominy and Wood 1986).

In contrast to upland sites, compact Sphagnum seedbeds in peatland depressions maintained good areal coverage for a much longer period. This suggests there is greater leeway in the timing of seeding operations and better opportunities for reseeding these lowland depressions. However, competition from other vegetation, including the Sphagnum itself, remains a concern (Groot and Adams 1994).

\section{Conclusions}

The areal coverage and receptivity of good seedbeds often declines on coarse-textured, black spruce upland sites after the first growing season following scarification. Of the principal receptive soil strata, Thin- $\mathrm{H}$ is the most ephemeral, whereas shallow-mineral was perhaps the most durable. This decline in seedbed coverage occurs more rapidly on sites with fresh Soil Moisture Regimes which are dominated by a variety of broadleafed trees, shrubs and herbs than on sites with moist Soil Moisture Regimes which are dominated by eracaceous shrubs. Likewise, in the absence of weed control, seedlings sown the first growing season after scarification grew more quickly in their first decade than seedlings sown the second or third growing season after scarification.
Seedling establishment ratios varied greatly from year to year on a given seedbed and site. Seeding in consecutive years, beginning the first growing season after scarification, is one means of overcoming the resulting uncertainty in seedling establishment.

\section{Acknowledgements}

This research was partially funded through the CanadaOntario Forest Resources Development Agreement (COFRDA, 1985-1990) and was a cooperative undertaking between Forestry Canada and the Ontario Ministry of Natural Resources. Assessments were completed under contract by Matcam Forestry Consultants, Silvico Forestry Services and Crossfield Environmental Ltd. The contributions of J.W. Fraser and T. Silc (CFS), F.C. Robinson and R.G. Klein (Ontario Ministry of Natural Resources) and private contractors D.A. Cameron, S.A. Lister, and S.C. McMurray are gratefully acknowledged.

\section{References}

Arlidge, J.W.C. 1967. The durability of scarified seedbeds for spruce regeneration. British Columbia Forest Service, Victoria, BC. Res. Notes No. 42.19 p. + Append.

Atmospheric Environment Service. 1982. Canadian Climate Normals, Vols. 1-6. Environ. Can., Atmospheric Environment Service, Ottawa, ON. 1650 p.

Benson, C.A. 1988. A need for extensive forest management. For. Chron. 64: 421-430.

Berbee, F.M. 1957. The ecology of some important mosses of the forest floor and the effect of these mosses on the establishment of coniferous seedlings. Can. Dep. Northern Affairs National Res., For. Br., Maritimes District. Project M. 342. Unpubl. manuscript.

Brown, G. 1973. Direct seeding in Ontario pp. 119-124. In J.H. Cayford (ed.) Direct Seeding Symposium, 11-13 September, 1973, Timmins, ON. Can. Dep. Environ., Can. For. Serv., Ottawa, ON. Publ. No. 1339. Clymo, R.S. 1970. The growth of Sphagnum: methods of measurement. J. Ecol. 58: 13-49.

Dominy, S.W.J. and J.E. Wood. 1986. Shelter spot seeding trials with jack pine, black spruce and white spruce in northern Ontario. For. Chron. 62: 446-450.

Fleming, R.L. and D.S. Mossa. 1994. Direct seeding of black spruce in northwestern Ontario: Seedbed relationships. For. Chron. 70: $151-158$.

Fleming, R.L. and D.S. Mossa. 1995. Establishment and growth of seeded upland black spruce: 7-12 year response. Nat. Resour. Can., Can. For. Serv., ON. Sault Ste. Marie, ON. NODA/NFP Tech. Rep. TR-8.

Fleming, R.L., D.S. Mossa and T.R. Burns. 1987. Scạrification trials for direct seeding on upland black spruce sites in northwestern Ontario. Govt. of Can., Can. For. Serv., Sault Ste. Marie, ON. Inf. Rep. O-X385. 47 p. + Appendices.

Fraser, J.W. 1981. Experimental seedspotting trials with black spruce on upland cutovers. Dep. Environ., Can. For. Serv., Sault Ste. Marie, ON. Inf. Rep. O-X-323. 23 p. + Appendix.

Groot, A. and M.J. Adams. 1994. Direct seeding black spruce on peatlands: fifth-year results. For Chron. 70: 585-592.

Haavisto, V.F. 1978. Lowland black spruce seedfall: Viable seedfall peaks in mid-April. For. Chron. 54: 213-215.

Haavisto, V.F. 1982. The retention of seed viability in semi-serotinous black spruce cones. pp. 92-95 In B.S.P. Wang (ed.) International symposium on forest tree seed storage. Can. Dep. Environ., Can. For. Serv., Ottawa, ON. 243 p.

Hellum, A.K. 1973. Direct seeding in western Canada. pp. 103-111 In J.H. Cayford (ed.) Direct seeding symposium. Can. Dep. Environ., Can. For. Serv., Ottawa, ON. Publ. No. 1339.

Janas, P.S. and B.D. Haddon. 1984. Canadian forest tree seed 
statistics: 1980-81 survey results. Dep. Environ., Can. For. Serv., Chalk River, ON. Inf. Rep. PI-X-41. 16 p. + Appendices.

Jeglum, J.K. 1979. Effects of some seedbed types and watering frequencies on germination and growth of black spruce: A greenhouse study. Dep. Environ., Can. For. Serv., Sault Ste. Marie, ON., Inf. Rep. O-X-292., 33 p.

Jeglum, J.K. 1984. Strip cutting in shallow-soil upland black spruce near Nipigon, Ontario: IV. Seedling-seedbed relationships. Dep. Environ., Can. For. Serv., Sault Ste. Marie, ON. Inf. Rep. O-X-359. $26 \mathrm{p}$.

Jeglum, J.K. 1987. Alternate strip clearcutting in upland black spruce II. Factors affecting regeneration in first-cut strips. For. Chron. 63: 439-445.

Jeglum, J.K. 1990. Low-cost regeneration in Ontario: What are the needs? In Proceedings of the Low Cost Regeneration Workshop, 10-11 October, 1990, Hearst, Ont., Ontario Ministry of Natural Resources, Northeast Region, Timmins, ON.

Jeglum, J.K. and J.-D. LeBlanc. 1988. The Ontario experience in natural regeneration of black spruce (Picea mariana (Mill.) B.S.P.) In M. Coté (ed.) Proc. Workshop on Mechanisms of Black Spruce Regeneration, Chicoutami, PQ 18 August 1988.

LeBarron, R.K. 1944. Influence of controllable environmental conditions on regeneration of jack pine and black spruce. J. Agric. Res. 68: 97-119.

MacLean, D.W. 1959. Five-year progress report on Project RC-17. Pulp and Paper Research Institute of Canada, Montreal, Quebec. Woodlands Research Index No. 112.142 p.

Morris, D.M., G.B. MacDonald and K.M. McClain. 1990. Evaluation of morphological attributes as response variables to perennial competition for 4-year-old black spruce and jack pine seedlings. Can. J. For. Res. 20: 1696-1703.

Ontario Institute of Pedology. 1985. Field manual for describing soils. 3rd Edition. Ontario Institute of Pedology, Guelph ON. 42 p.
Place, I.C.M. 1955. The influence of seed-bed conditions on the regeneration of spruce and balsam fir. Can. Dep. Northern Affairs and National Resources, For. Branch, For. Res. Div. Bull. 117. 79 p. + Appendices. Plonski, W.L. 1974. Normal yield tables (metric). Division of Forests, Ontario Ministry of Natural Resources, Toronto, ON. 40 p. Richardson, J. 1972. Direct seeding on a prescribed burn in western Newfoundland. Dep. Environ., Can. For. Serv., St. John's, NF. Inf. Rep. N-X-82. 15 p.

Rowe, J.S. 1972. Forest Regions of Canada. Dep. Environ., Can. For. Serv., Ottawa, ON. Publ. 1300. 172 p.

Rudolph, J.T. 1973. Direct seeding versus other regeneration techniques: silvicultural aspects. pp. 29-34. In J.H. Cayford (ed.) Direct Seeding Symposium, 11-13 September, 1973, Timmins, ON. Can. Dep. Environ., Can. For. Serv., Ottawa, ON. Publ. No. 1339.

Sims, R.A., W.D. Towill, K.A. Baldwin and G.W. Wickware. 1989. Field guide to the forest ecosystem classification for Northwestem Ontario. Northwestern Ontario Forest Technology Development Unit, Ontario Ministry of Natural Resources, Thunder Bay, ON. 191 p.

Van Damme, L. 1988. Sowing method and seed treatment effects on jack pine direct seeding. North. J. Appl. For. 5: 237-240.

Viereck, L.A. and W.F. Johnston. 1990. Picea mariana (Mill.) B.S.P. Black Spruce pp. 227-237 In R.M. Burns and B.H. Honkala (Tech. Coord.) Silvics of North America. Vol. 1, Conifers, USDA For. Serv. Washington, DC, Agricultural Handbook 654.

Wang, B.S.P. 1974. Tree-seed storage. Dep. Environ., Can. For. Serv., Ottawa, ON. Publ. No. 1335. 30 p. + Appendix.

Winston, D.A. 1975. Black spruce seeding experiments in the Central Plateau Section B.8, Manitouwadge, Ontario. pp. 125-139 In Black Spruce Symposium. Dep. Environ., Can. For. Serv., Sault Ste. Marie, ON. COJFRC Symp. Proc. O-P-4. 289 p. + appendices. Zar, J.H. 1984. Biostatistical analysis, 2nd ed., Prentice-Hall, Inc., Englewood Cliffs, NJ. 718 p. 